\title{
Anthropology as a metaparadigm in modern scientific knowledge
}

\author{
Rozaliya Rupova ${ }^{1, *}$ \\ ${ }^{1}$ Russian State Social University, Moscow, Russia
}

\begin{abstract}
The "anthropological turn" of the twentieth century, as well as the crisis of European science, the transition to a non-classical language both in philosophy and in other areas of thought, the entry of culture into the postmodern stage - all this entailed a rethinking of the "theme of human" itself. In the spectrum of new anthropological approaches, the question of man in the East Christian tradition has gained particular importance. Proclaimed in 1936 by Georgy Florovsky, "Neopatristic synthesis" opened the prospect of renewing the dialogue between Christianity and modernity. The paper analyzes the transformations of ideas about man and society that took place in the postmodern era. The ways of forming a new language for describing a person and society, correlating with the language of nonclassical scientific discourse, are proposed.Based on an analysis of the latest research, the author considers the possibility of using the language of the spiritual tradition of Christianity to describe forms of social and anthropological reality, which in our time can no longer be described in the language of classical discourse. The work also substantiates the paradigmatic status of the anthropology of East Christian discourse.
\end{abstract}

\section{Introduction}

Successively replacing each other, large-scale crises of the twentieth century exceeded the turn of the millennium. The specificity of their newest nature is that they not only relate to certain areas of society, but affect the person himself, have moved to the anthropological level. The global dynamics of our time, the scale of social transformations leaves is out the factor of the relationship with deep anthropological dynamics. Which person will take advantage of the transformation? Who is able to take responsibility to solve a complex set of socio-historical problems, manage social institutions and determine politics?

"European humanity has reached a dead end, and this consciousness is even more tragic in that the technical and material power of culture remains unchanged". This phrase, uttered by V. Zenkovsky half a century ago in the article "The Idea of Orthodox Culture", has not lost its relevance for our days. The twentieth century was marked by an "anthropological turn", when the most diverse sciences concentrated their attention on man. It was a consequence of the evidence that the root crisis that spawned all the others was an anthropological crisis. Scientists are not even talking about a "crisis", but about a "disaster": "among the many disasters that are famous the twentieth century, one, the main and often

\footnotetext{
* Corresponding author: rozaliya-rupova@yandex.ru
} 
hidden from the eyes is an anthropological disaster" (Mamardashvili M. "Consciousness and Civilization").

Currently, almost all areas of scientific research, whether in the humanities or in the natural sciences, are seeking reserves - environmental, economic, psychological, sociocultural, etc. - to increase the stability of human life and society. This work is written in the same vein. The author sees the resources for overcoming the crisis-catastrophic state of modern society and the transition to positive sociocultural dynamics in turning to the spiritual tradition of Christianity. "Modern European culture arose from Christianity, which created cultural forms of organizing life, using for this not only the experience of the Old Testament, but also the richest Greek and Roman culture of social organization, philosophical thought and artistic creativity. The history of Europe is a long process of Christianization of all areas of culture, of the entire cultural heritage of peoples that are gradually entering the Christian Ecumene" (Schrader Y. Christ - the source and basis of the new European culture). Christian culture was purposefully built as a system. It had a synthetic character - all the creative undertakings of the past were combined in a large-scale synthesis. Hellenism became a church. The assessment of this process fluctuates between two extreme points: "Hellenization of Christianity" (by A. Harnack) and "Christianization of Hellenism." Georgy Florovsky resolutely refutes the first formulation. The essence of Byzantine culture was a Christian rethinking, a reappraisal of Hellenism. At the same time, the history of Christian culture is accompanied of struggle and conflicts.

It is important to clarify the relationship between Christianity and culture, because the concept of neo-patristic synthesis we are considering is a form of ongoing dialogue between Christianity and modern culture, an opportunity to realize in culture a creative socially productive resource of an ancient tradition. The goals of Christianity go beyond culture, beyond history itself. It is itself a judgment on history. At the same time, many different teachings and beliefs are circulating in culture, claiming the status of truth. Scientific theories throughout the New and Modern times, with all their changes, acquired the status of a religious dogma. It can be argued, and the experience of history gives us many examples, that when people rally around a false idea, it has disastrous consequences. European civilization owes its existence to the creative impulse that Christianity gave it on the ruins of antiquity. When the generative impulse is depleted and loses its strength, the culture "dies out", falls into decay. This is exactly what is happening now before our eyes. The solution to the question suggests itself - the "dying" European civilization should be renewed through an appeal to its nourishing source - Christianity. This, in fact, is what the concept of neopatristic synthesis calls for.

The importance and enduring relevance of the study of the religious life of society is noted by the professor of the RSSU I.M. Melikov: "Throughout the history of society, from the very beginning to the present, there is always a religious background to events. ... We will not find a single sphere in public life, not a single question that would not have religious roots. Modern economics, economic principles, are consequences of certain religious ideas. In cultural and political life the same thing" ("The Spiritual Being of Freedom").

Towards the end of the twentieth century, personalism, which was, in fact, a manifestation of an anthropological turn in philosophy, gave rise to such a phenomenon as "personality theology", which indicates that the field of theology was also anthropologized. At first glance, there is a fundamental contradiction, contradictio in adjecto (lat). But, as archpriest John Meyendorf put it, "it has now become a commonplace to state that theology should become anthropology in our time." («Orthodoxy in the modern world»). What does this anthropologized theology consist of? It is based on a special anthropology characteristic of the Christian understanding of man. At its base is a view of man as a fundamentally open being, and not autonomous and self-sufficient; his humanity, first of all, is open to the Absolute, immortality, creativity, in the image of the Creator. Communion with the glory of 
the divine life and communication for man is natural. This is anthropological theology and can assume the role of metadiscourse. Through this prism, you can look at all types of human activity and bring them to a common denominator.

The basis of the so-understood theology, as well as culture and science, is one and the same person. Theological thought, in principle, can never be separated from life. Accordingly, all forms of sociality, such as culture, philosophy, politics and science, are established and investigated in the perspective of communication with God. Thus, theology ceases to be a discipline divorced from life and is extremely actualized, becoming the acting force of modern social practice. As Metropolitan Callist Ware wrote, "Our privacy, personal relationships, and all our plans to build a Christian society depend on a proper understanding of Trinitarian theology." («God and humanity»).

Such creative theological potential is concentrated in by the concept of neopatristic synthesis. It also contains resources for overcoming the crisis and catastrophic state of modern society and the transition to positive socio-cultural dynamics, since it actualizes the Christian tradition, which has already manifested itself in the history of Europe, when it saved it from barbarization in the period of late antiquity.

Its inspirer was the greatest philosopher and theologian of the twentieth century, a representative of the Russian post-revolutionary emigration, Archpriest George Florovsky (1893 - 1979). It was he who formulated the idea of neopatristic synthesis in 1936, and his slogan "Forward to the Fathers!" became the banner of the West European "patristic revival", embracing the religious philosophy of the twentieth century, cultural and social spheres, revealing to the world the treasures of Eastern Christian thought and spiritual tradition. The concept of neo-patristic synthesis developed into a whole intellectual movement of the 20th and 21 st centuries, and created a wide problem field in the cultural horizon of our time. His task was to rethink the patristic heritage of the Christian Church in order to address pressing issues of modern life.

The neo-patristic synthesis, which we are considering, is rooted in patristics, the same one has as its core the mystical-ascetic tradition of hesychasm. Research in this tradition today constitutes a vast interdisciplinary field that has been in active development for several decades.

The aim of the study is to comprehend and justify the paradigmatic status of anthropology of East Christian discourse. Due to the existence of well-known ideological limitations in Russia for decades, Western research has gone far ahead. But, starting from the last decade of the past century, domestic science has been actively involved in this process. Translations of Western European authors, as well as the works of Russian scientists, began to be published in Russia. Among the latter, works of S.S. Horujy [1,2,3] and of the school he created.

In addition, we will name a number of authors who have contributed to the development of this problem field: Shtekl K. [4], Mikhailov P.B. [5], Solonchenko A.A. [6,7], Mahler A.M. [8], Fufaev S. [9]. Studies by the author of this article have also been carried out in the same direction $[10,11,12]$. Modern aspects of studying the Christian tradition are reflected in the studies of Western scholars - world famous and just beginning to develop this topic: Nesteruk A.V. [14], Ware K. [15], Chul Min Jun [16] and others.

\section{Materials and methods}


This study examines anthropological issues in its formulation in the framework of religious discourse. The dialogue of this discourse with secular, as well as the whole range of tasks posed in the work, is studied within the framework of secular discourse with the help of tools developed by European philosophy. Along with the classical methods of scientific research, the phenomenological method of examining objects belonging to the spiritual tradition is of particular importance for the author - this allows us to consider them "from within the tradition itself."

A philosophical study of religious issues is becoming especially relevant today, when the intensification of religious life in various forms is combined with the undetermined relationship between religion and society. Moreover, the model of these relations is chosen between two extremes - "Soviet", when religion is proclaimed a semi-legal sphere of private life of citizens, or "Byzantine", when religion is an official institution based on the power of the state and is controlling almost all aspects of public life It may be notice that the difficulty of determining the place of religion in society is not a purely Russian specificity. Yu. Habermas, a modern Western philosopher and sociologist who has devoted a number of works to this issue, concludes that "the vagueness of the theoretical order in the analysis of communicative norms (in the dialogue of secular and religious discourses - RR) and in the principles of public life can lead in practice to catastrophic consequences " ("Habermas J., Ratzinger J. Dialectics of secularization"). The essence of these ambiguities is the lack of elaboration of the relationship between religious discourse and secular discourse.

Starting from the Renaissance, over the centuries, secular discourse in European society has become increasingly powerful and has become dominant. This raises the question of the degree of its universality; Is it not just one of the possible communication systems? From the fact that religion is affirmed in society by the private affair of an individual, the erroneous conclusion is drawn that the religious discourse as such belongs to the private sphere and does not have wide social significance. Currently, the universality of secular discourse is being called into question. Along with this, the question arises of a different ethical and communicative basis of modern society, of a change in the place of religion in it. The idea of "post-secularity" arises, which is mentioned in the dialogue held between J. Ratzinger and J. Habermas. However, the difficulty is that the development of this idea does not at all mean a rejection of secularity as such. The problematic nature of secularization lies in the fact that its first ideologists were not atheistic government officials at all, but St. Francis of Assisi and St. Nil Sorsky.

Thus, many of the concepts used by modern science of society require clarification. In particular, such a concept as secularization should be given a broader meaning.

\section{Results}

Florovsky argued that "if you can even talk about some kind of "Christian metaphysics", then this should be a metaphysics of personality ( St. Gregory Palamas and the tradition of the fathers»). It is in the individual, and not in the state, society or any other collective, that the absolute principle is revealed, the personal principle should not be sacrificed to the corporate one. According to Prot. George Florovsky, "The human person goes beyond the limits of history" («Christianity and Civilization»). It is also irreducible to the natural principle, for it has "the supernatural task of free <...> communion with God" («Creature and Creativity»). Theological anthropology takes upon itself constructive criticism of all spiritually limited ideas about a person, considered only as a product of natural evolution or social programs. The theology of personality, which has adopted these attitudes and is based on the ascetic anthropology, can serve as a tool for analyzing and diagnosing socio-cultural practices. The value and justification for applying the idea of neopatristic synthesis in the modern world can only stem from the desire of theology to have a transformative effect on the world in all its 
aspects, including nature, human society, as well as its scientific, technological and political dimensions.

The concept of neopatristic synthesis has accumulated the latest achievements of the theology of personality and other areas related to the theological analysis of different aspects of life. But at the same time, with all its "right" appeals, it may remain a pure theory if it is not brought into the mainstream of socio-historical practice. The spiritual experience contained in Tradition will be a "museum treasure", but not a tool for planning cultural transformations until it acquires a methodological status. This methodological uncertainty of the concept of neopatristic synthesis was its characteristic feature, transforming into abstract theorizing the spiritually verified and highly substantive attitudes of its creators. The way to build the concept of neopatristic synthesis as a tool of historical creativity is, first of all, the full inclusion of hesychasm in it, which is thoroughly meaningful in the Tradition and structured anthropological practice, which opens up the prospects for the implementation of the Christian ideal of the transfiguration of man, his deification. This ideal, with all its seeming unattainability, should nevertheless have as a target. Otherwise, he will be replaced by the image of a posthuman cyborg. Otherwise, he will be replaced by the image of a posthuman cyborg. This shift in emphasis towards hesychasm as practice, transforms neopatristic synthesis from a pure theory into a model of the historical process, a tool for strategic planning of cultural transformations. The conceptual understanding of the formation of a new configuration of the concept of neopatristic synthesis finds its descriptive means in the arsenal of non-classical philosophical discourse of the twentieth century. The hermeneutic approaches in its analysis are connected, first of all, not with the hermeneutics of texts, but with the hermeneutics of experience. The installation of a direct appeal to patristic and ascetic experience ... brings the concept closer to the mainstream of phenomenology, the sources of which, according to Husserl, are the appeal to "things themselves", to direct experience.

\section{Discussion}

Let's note one more important point. The leading impulse of the concept of neo-patristic synthesis is the appeal to the authoritative testimony of the Church Fathers. Attacks on patristic tradition and on the principle of the consent of the fathers (consensus patrum) as such have now intensified. The followers of patristic heritage are accused of fundamentalism. In particular, the article by the Greek author G. Demakopoulos says: "The key intellectual error of Orthodox fundamentalism lies in the assumption that the Church Fathers are in agreement on all theological and ethical issues".

The arguments of modernists against the principle of "consensus patrum" can be summarized as follows:

1. An indication of doctrinal inaccuracies, differences of opinion.

2. Erroneous, outdated views on the structure of the universe.

With regard to the accusation of paragraph 1 , in response to the modernists we can say that the principle of "consensus patrum" does not mean at all that all the fathers say the same thing with one voice. There were cases of erroneous opinions - such were, for example, among the hierarchs Gregory of Nyssa and Epiphanius of Cyprus.

Saint Mark of Ephesus discusses this topic as follows: "There is a big difference between what is said in the canonical Scriptures and the Tradition of the Church - and what was written in a private way by a separate of the Teachers. So - in the first, given by God, we must believe; and in the second, we must not unconditionally believe or accept without asking. For it is possible that someone is also a Teacher, and yet not everything is absolutely correct. For what need would the fathers have in the Ecumenical Councils if each of them could not deviate from the truth in anything?" (Mark of Ephesus, saint. The second word about the cleansing fire, 15). 
As for item 2 of the attacks on the principle of "consensus patrum", it must be said that nowhere and never in the presentation of the Orthodox doctrine was it said that everything written by the holy fathers on any issue is divinely inspired, infallible, and none of them had no contradictions. Such a position makes senseless the very principle of "consent of the fathers" - what kind of agreement can we talk about if they all teach identically to each other? In addition, the consensus patrum dealt exclusively with issues of direct relevance to salvation - it did not deal with topics of natural science, socio-political or aesthetic. The very concept of neo-patristic synthesis is also criticized.

Theology can be in dialogue with secular processes, playing the role of a feedback system that criticizes secular modes of consciousness. Carrying out such criticism, theology asserts itself as a meta-discourse that surpasses not only all socio-historical sciences, but also any comprehensive philosophical systems. Theology, in principle, can never be determined by the secular mind and can never accept the autonomy of natural-science rationality. For our position it is important that, according to Vl. Lossky "Theological anthropology should be built from top to bottom, proceeding from the Trinity and Christological dogmas ..." («Katholic consciousness»). The doctrine of the human person is formed by analogy with the doctrine of the Holy Trinity and the corresponding theological terminology is very suitable. Since patristics distinguishes nature and hypostasis in God, these concepts are also used in the examination of man. The divine essence is compared with human nature, and the divine hypostasis is correlated with the human person.

St. Gregory Palamas (1296 - 1359), whose name is associated with the doctrine of the Divine energies, does not limit his doctrine only to the divine life, but finds analogues, or symbols, in the dispensation of man. In the mainstream of palamism, man is considered in research strategies of Horujy S.S. "as a kind of energy formation, i.e. the totality or configuration of all his energies, physical, mental and intellectual. Human energies are in constant motion, in change ... The energy configuration or energy image is a moving, changing characteristic" («Society and Synergy: Colonization of the Interface»). Orthodox theology is based on such anthropology, it is the basis for Hesychasm, and its foundation is the Palamite discourse of energies.

In the current situation new knowledge is emerging at a faster pace and is having an increasing impact on society. The energy discourse is becoming universal before our eyes, being prescribed in the most diverse spheres of life - in theology, anthropology, social philosophy, and the exact sciences. In theoretical physics, for example, a number of researchers in search of a theory linking the four fundamental interactions (gravitational, electromagnetic, weak and strong) into a single system, have hopes for superstring theory, discovered in the 70s of the twentieth century. According to this theory, at the microscopic level, everything consists of combinations of vibrating energy "fibers" - strings. This theory provides a single (so far only mathematical) way of explaining the properties of all interactions, all types of matter, as well as space-time. The energy perception of the material world has already become the property of modern science. "There is deep reason to believe that the entire Universe, including, apparently, the "solid" substance perceived by our senses, is just a manifestation of a sinuous nothing. The world ultimately turns out to be a cast of absolute emptiness, a self-organized vacuum” («Davis Paul "Superpower"»).

The twentieth century gave rise to such a phenomenon as postmodernity, which affected all aspects of society and the man himself. Postmodernism first emerged as a phenomenon at the intersection of art and art criticism, interpreting the experience of neo-avant-garde movements after the Second World War. In the 70s - 80s of the twentieth century, he began to claim the role of spokesman for the intellectual and emotional spirit of the era, for a leading position in philosophy, in science, in politics, in fashion. His generic distinction was total pluralism. Postmodernism has become an expression of the culture of post-industrial society, which has come to replace the traditional industrial bourgeois society in the West. In a post- 
industrial society, information is the most valuable commodity; at the same time, the old values fall under deconstruction, have no sense. What is the peculiarity of the post-modern anthropological attitudes integrated into its ideological and philosophical movements?

Postmodernism made a radical reorientation of philosophical thought: 1) "the ban on metaphysics"; 2) the rejection of the causal relationship in the world and the vision of objectivity as being in the process of continuous self-organization; 3) a radical rejection of binary oppositions of the type subject - object, female - male, East - West, etc .; 4) the proclamation of the absence of the meaning of being. Postmodernism had its own specifics in the field of social philosophy. He revised the entire conceptual apparatus on which the socio-philosophical discourse is built. As a result, he abandoned the very concept of "society." Taking into account the attitudes toward the chaotization and textualization of the world, society was defined as the sphere of a social text; the personality was interpreted as a self-narration of "open identity". A person in the interpretation of postmodern is nothing more than a residual reality. Theorists of postmodernism exclude the possibility of rational justification of human society, the meaning of life, morality. Only "microethics", permeated with the spirit of disorientation and skepticism, is possible, which is not connected with the concepts of Good or Truth.

The "death of the subject," proclaimed in postmodernism, is the very extreme point, the boundary, to which, with inevitability, led the five hundred-year path of European Humanism.

The doctrine of society in the postmodern era has also undergone radical changes. Nonclassical and, then, post-non-classical philosophy gave rise to the corresponding social philosophy. Understanding of sociality in this type of discourse began to be interpreted eventfully as fields, practices, structures, a transition from an essential to an existential interpretation of society was outlined. Sociality being is no longer understood as a pile of social structures and institutions. Social ontology is dynamic in which stable structures are forms derived from interactions arising in the process of communication and joint activities of people. In such an energetic, procedural paradigm, "society is a combination of energies embodied by various entities in the framework of creating certain conditions for joint existence. The combination of such energies forms the life world of the era, sets the vectors of the sociocultural situation.

If we take informational, financial, and traffic flows, we will see the same energetic nature everywhere that correlates with the energetic understanding of man in hesychast anthropology.

Metropolitan John Zizioulas in the famous book "Being as Communion" substantiated the primacy of communication in the being of the Holy Trinity. Personal beingcommunication is constitutive for the human person. But, if we turn to society, then in it communication is the dominant and all-encompassing element, with a variety of forms, types, technologies. In recent times, this variety is most actively developed and dominated by media, by virtual forms and communication technologies.

In his theology John (Zizioulas) uses the term "individual" as a concept opposite to "personality." The individual, in his opinion, can be understood as an identity, conceivable "regardless of anything else", or as an "axis of consciousness", or as a combination of natural or moral qualities ("Communion and Otherness"). Zizioulas believes that this concept does not apply to Divine Persons. In anthropology, he uses it to describe human existence after the fall. The individual is characterized by Zizioulas as part, a fragment of the whole, something isolated. This concept carries a shade of individualism, self, isolation on itself. The concept of "individual existence" as a closed being, Ziziulas contrasts personal existence, as being ecstatic, correlative, open in relation to another. The highest manifestation of the image of God in man is his personality, understood as the ability or opportunity (embedded in human nature by God) to be a person. Personality and a person in the anthropology of Zizioulas can 
be correlated with the image and likeness of God in man. Likeness to God, deification ("Being as Communion") is the tropos (mode) of human being, similar to the tropos of the being of God, that is, being in love / fellowship. Moreover, love is not a feeling or emotion. "Love is a relationship", overcoming one's self in favor of another, free recognition and affirmation of its uniqueness and irreplaceability ("Communion and Otherness"). Thus, deification and personality are "created by love" ("Communion and Otherness") by communication directed towards God as a person par excellence, and to a person as a person by calling (in potency). "The apogee of this ontological communion (love) is the Eucharist, as a manifestation of the Church. The theology of communication is Eucharistic theology, which means it is impossible to talk about the theology of communication outside of ecclesiology, that is, the social dimension of the Church" [17].

After the scientific revolution that took place at the turn of the nineteenth and twentieth centuries, a new scientific paradigm emerged. Then, in relation to quantum physics, Niels Bohr formulated the principle of complementarity, according to which the objects of the microworld simultaneously exhibit corpuscular and wave properties. This discovery was fundamental in nature and in its significance went far beyond physics. It showed the inadequacy of classical logic to describe the picture of the world.

The Christian doctrine of the God-manhood of Christ, of the Church, which "is at the same time the Body of Christ and the fullness of the Holy Spirit, "filling everything in everything" also does not fit into the framework of classical logic. As can be seen in the examples examined, the scientific episteme of modernity is completely ripe for an adequate perception of Christian dogma, that not easy, indeed, for secular consciousness. We can say that secularism itself was also generated by anthropology deformed at the beginning of the New Age, from which the "vertical" was removed, namely the understanding of man as the image of God, present in him as a living and effective principle.

\section{Conclusions}

It becomes obvious that the actualization of the dogma of the Church and, above all, Christian anthropology, in modern society is the most important task of theology. The ultimate goal of all theology is deification.

The dogma, as the actualization of truth, is a symbol that indicates to the church community the path to this deification. The theologian's task is to give a clear explanation, to interpret the dogma so that it can fulfill its destiny.

The language of modern science, the newest philosophical thought, can do for theology such service, just as at the dawn of the patristic era, this service was rendered to him by ancient philosophy. The mystery of the Incarnation, the main mystery of the universe (as Protopriest George Florovsky asserted), leads us to the idea of the need for "humanizing the entire cosmos, transforming it into a macro-anthropos, and then bring all the creature together with man to deification. According to the thought of St. Maximus the Confessor, a man is not called to become "cosmosed", but in order for the cosmos to become humanized. Under conditions of instability and active dynamics of the anthropological picture of the third millennium, the anthropology of the Eastern Christian tradition, based on a detailed hesychasm practice, acquires the status of a metadiscourse.

"The anthropological perspective that absorbs - in potency - the entire community of humanitarian discourses and, at the same time endowed with its own epistemological paradigm, becomes a unifying principle, the general methodological basis of this community, becomes an enveloping epistemological formation - what can be called an epistem ..."anthropological epistem"- a radically new image and status of anthropology" (Horujy S.S. «Foucault's latest project. «Practices of self» and spiritual practices»). Thus, theological 
knowledge in its anthropological projection is destined to mediate between all other forms of knowledge in human culture.

We are faced with a complex task of philosophical interpretation of theology and, at the same time, theological comprehension of modern scientific knowledge. Such comprehension aims not only to fill the empty place of the Creator in the materialistic scientific approaches prevailing until recently, but to reveal and substantiate the connections of natural science laws (and, moreover, social laws) with deeper truths of a moral nature that touch on the meaning of human existence, its mission and responsibility In our time of the technological simplicity of the destruction of peoples and states, these questions are put forward at the forefront of any science. It is in these themes that the heritage of the Church Fathers is invaluable, since it contains the understanding of man that is in demand in our era. In the mainstream of neo-patristic synthesis, the appeal to the fathers occurs not so much for answers as for methods of obtaining them. Archpriest Georgy Florovsky wrote about the need to check the complex issues of our time with the fathers, by no means limiting them to a purely dogmatic sphere. His expression "to acquire the minds of the fathers" orients us to the fact that in those most difficult questions that the modern world puts before a person and society, one should follow the path of the fathers, realizing that the range of issues that are indifferent to salvation has been very narrowed.

\section{References}

1. S.S. Horujy, Philosophy and Culture 5, 721 - 729 (2016) https://doi.org/10.7256/19992793.2016.5.18812

2. S.S. Horujy, Culture and art 1, 25 - 40 (2016) https://doi.org/10.7256/22221956.2016.1.16838

3. S.S. Horujy, Philosophy and Culture 2, 268 - 274 (2016) https://doi.org/10.7256/19992793.2016.2.16982

4. K. Shtekl, Church in Russia and abroad 36(3), 195-223 (2018) https://doi.org/10.22394/2073-7203-2018-36-3-195-223

5. P.B. Mikhailov, Bulletin of the Orthodox St. Tikhon Humanitarian University. Series 1: $\begin{array}{lllll}\text { Theology. Philosophy. Religious studies 71, 50-68 (2017) } & \end{array}$ DOI: $10.15382 /$ sturI201771.50-68

6. A.A. Solonchenko, Questions of theology 1(1), 30-43 (2019) DOI: 10.31802/26587491-2019-1-1-30-43

7. A.A. Solonchenko, Social policy and sociology 17.3(128), 119-125 (2018) DOI: 10.17922/2071-3665-2018-17-3-119-125

8. A.M. Mahler, Notebooks on conservatism 3, 131-138 (2019) DOI: 10.24030/240925172019-0-3-131-138

9. S. Fufaev, Theological Bulletin 35(4), 38-71 (2019) DOI: 10.31802/2500-1450-201935-38-71

10. R.M. Rupova, Social policy and sociology 17.2(127), 186-193 (2018) https://doi.org/10.17922/2071-3665-2018-17-2-186-193

11. R.M. Rupova, Social policy and sociology 17.3(128), 111-118 (2018) DOI: 10.17922/2071-3665-2018-17-3-111-118

12. R.M. Rupova, Prospects for science and education 2(44), 171-178 (2020) doi:10.32744/pse.2020.2.14

13. J.K. Larcher, Questions of theology 1(2), 199-220 DOI:10.21638/spbu28.2019.202

14. A.V. Nesteruk, Journal of the Siberian Federal University. Series: Humanities 9(9), 2150-2183 (2016) DOI: 10.17516/1997-1370-2016-9-9-2150-2183 
15. Chul Min Jun, Pacific Science Review 16, 156-166 (2014) https://doi.org/10.1016/j.pscr.2014.08.028

16. R.M. Rupova, A.A. Solonchenko, Social policy and sociology 18.4(133), 118-125 (2019) DOI: 10.17922/2071-3665-2019-18-4-118-125 